\section{MINNE MENET, VELKOJIENSUOJA YHTEISÖOIKEUDESSA?}

\section{Jukka Mähönen ${ }^{1}$}

DOI: https://doi.org/10.33344/vol14iss1pp8-11

Helsinki Law Review, 1/2020, pp. 8-11

(c) 2020 Pykälä ry, Mannerheimintie 3 B, 5th floor, 00100 Helsinki, Finland, and the author.

Osakeyhtiöiden ja osuuskuntien sääntelyn ydin on 1800-luvulta lähtien ollut velkojien suojaaminen. ${ }^{2}$ Sitä on perusteltu ennen kaikkea näiden yhteisömuotojen täydellisellä oikeushenkilöllisyydellä ja sillä, että niiden jäsenillä ei ole henkilökohtaista vastuuta yhteisön velvoitteista. ${ }^{3}$ Yhteisölakien ydin onkin niissä olevissa maksunsaantijärjestyksissä yhteisön eri jäsen- ja sijoittajaryhmien välillä. Maksunsaantijärjestyksellä ja sitä konkretisoivilla varojenjakoa ja velkojiensuojaa koskevilla säännöksillä on pyritty suojaamaan yhteisöön varoja sijoittaneita yhteisön jäsenten (joita osakeyhtiössä kutsutaan osakkeenomistajiksi ja osuuskunnassa jäseniksi) opportunismilta.

Varojenjakosäännökset, velkojien suostumusta koskevat säännökset esimerkiksi yritysjärjestelyissä, yhteisön jäsenilleen suuntaaman rahoituksen rajoittaminen ja oman pääoman menettämiseen liittyvät yhteisön johdon velvoitteet ovat muodostaneet rakenteen, jolla on pyritty suojaamaan muiden sijoittajien kuin yhteisön jäsenten, ja yhtiöstä riippuvien muidenkin etutahojen, asemaa yhteisössä jäsenten opportunismilta. Muita historiallisia keinoja ovat olleet vähimmäispääomasäännökset ja velvollisuudet kerryttää tietty määrä omaa päämaa yhteisöön. Näistä jälkimmäisistä säännöksistä on kuitenkin maailmalla pitkälti luovuttu viime vuosikymmenten aikana - viimeksi Suomessa vuonna 2019 yksityisten osakeyhtiöiden ja osuuskuntien osalta. ${ }^{4}$ Jäljelle on jäänyt julkisten osakeyhtiöiden vähimmäisosakepääomaa koskeva säännös, joka perustuu Euroopan unionin sääntelyyn, vaikkakin osakeyhtiölaissa asetettu 80.000 euron raja on moninkertainen edellytettyyn verrattuna. ${ }^{\mathbf{5}}$

Olemme kuitenkin huomanneet, että velkojiensuojasäännökset ovat tylppiä aseita turvaamaan muiden kuin jäsenten asemaa yhteisössä. Velkojien ja muiden yhteisöstä riippuvien

OTT, osuuskuntaoikeuden professori, Helsingin yliopisto, oikeustieteen professori, Oslon yliopisto.

2 Suomessa vuoden 1895 osakeyhtiöistä annetusta laista (22/1895) ja vuoden 1901 osuustoimintalaista (22/1901) lähtien

3 Olemme käsitelleet laajasti velkojiensuojaa Seppo Villan kanssa muun muassa teoksessa Osakeyhtiö II: Pääomarakenne ja rahoitus. 4., uudistettu painos. Alma Media 2020, erityisesti s. $411 \mathrm{ss}$.

4 Ks. laki osakeyhtiölain 1 luvun 3 §:n muuttamisesta (184/2019) ja laki osuuskuntalain 16 luvun 7 \&:n 1 momentin kumoamisesta (186/2019). Ks. tarkemmin HE 238/2018 vp yksityisen osakeyhtiön vähimmäispääomavaatimuksen poistamista koskevaksi lainsäädännöksi.

5 Euroopan parlamentin ja neuvoston direktiivi (EU) 2017/1132, annettu 14 päivänä kesäkuuta 2017, tietyistä yhtiöoikeuden osa-alueista (kodifikaatio), EUVL L 169, 30.6.2017, p. 46-127 (yhtiödirektiivi), 45.1 artikla, jonka mukaan julkisen yhtiön merkityn pääoman on oltava vähintään 25.000 euroa. Merkityistä osakkeista tarvitsee kuitenkin olla maksettuna vain 25 prosenttia, ks. 48 artikla. intressissä on, että sijoitetulle rahoituspääomalle ja muulle pääomalle, kuten inhimilliselle pääomalle, maksetaan tuottoa, olipa se korkoa velkojalle tai palkkaa työntekijöille, ja yhteisöä kehitetään tulevaisuutta varten. Olemme myös huomanneet, että velkojiensuojasäännökset eivät kannusta investointeihin eikä varojenjakoa mitoiteta suhteessa tulevaisuudennäkymiin. Toisaalta olemme huomanneet COVID-19-pandemian aikana, että varojenjakoa rajoitetaan yhteisöissä rationaalisesti tulevaisuudennäkymien olennaisesti heiketessä ja yhteisöjen olemassaolon vaarantuessa.

Osittain nämä onnistumiset johtuvat yhteisölakien ehkä terävimmistä aseista, liiketaloudellisen perusteen vaatimuksesta yhteisön varoja käytettäessä ${ }^{\boldsymbol{6}}$ ja maksukykyisyysvaatimuksesta, jonka mukaan varoja ei saa jakaa, jos jaosta päätettäessä tiedetään tai pitäisi tietää yhteisön olevan maksukyvytön taijaon aiheuttavan maksukyvyttömyyden. ${ }^{7}$ Nämä vaatimukset, toisin kuin useat muut velkojiensuojasäännökset, sopeutuvat yhteisöjen välillä oleviin valtaviin eroihin, jotka liittyvät yhteisön kokoon, jäsenten lukumäärään sekä yhteisön muuhun asemaan markkinoilla ja yhteiskunnassa. Perinteiset velkojiensuojasäännökset ovat jäykkiä, haittaavat pienimuotoista yritystoimintaa ja ovat kalliita toteuttaa. Osittain tämä johtuu yleislakiajattelusta: osakeyhtiölain on sopeuduttava kaikkien osakeyhtiöiden tarpeisiin pienestä kioskitoimintaa pyörittävästä yhdenyhtiöstä monikansallisiin useilla markkinapaikoilla listattuihin konglomeraatteihin. Toisaalta vuoden 2006 osakeyhtiölailla omaksutun sääntelyideologian mukaan osakeyhtiölain on sovelluttava lähes sellaisenaan myös muihin yhteisömuotoihin kuin osakeyhtiöön. Tämä näkyy selvästi vuoden 2013 osuuskuntalaissa, joka on pitkälti osakeyhtiölain kopio, niin hyvässä kuin pahassa. Näin osuuskuntalainkin on sopeuduttava muutaman freelancerin työosuuskunnista markkinajohdossa oleviin ja pörssiyhtiöitä kontrolloiviin osuuskuntiin.

Liiketaloudellisen perusteen ja maksukykyisyyden säilyttämisen vaatimukset osoittivat toki tehonsa jo ennen koronaviruspandemiaa, mutta pandemia on viimein vahvistanut, että ne ovat käytännössä tehokkaat keinot suojata yhteisöä ja sen etutahoja jäsenten ylisuurilta tai ennenaikaisilta vaatimuksilta. Tämä nähtiin selvästi kevään 2020 yhtiökokouksissa ja osuuskunnan kokouksissa. Sattuvasti kesällä 2020 julkaistiin lisäksi Tampereen yliopiston ja Lapin yliopiston valtioneuvoston kanslian toimeksiannosta toteuttama osakeyhtiön velkojiensuojan selventämistä ja suojamenettelyiden helpottamista koskeva selvitys. ${ }^{8}$ Selvityksessä kartoitettiin osakeyhtiölain velkojiensuojasäännösten ajantasaisuutta ja muutostarpeita tunnistaen seitsemän eri kehityskohdetta liittyen oman pääoman menettämiseen, omien osakkeiden hankinnan rahoittamiseen, perinteisen yhtiön taseeseen perustuvan testin rooliin

6 Osakeyhtiölain (624/2006) 13 luvun 1 \&:n 3 momentti ja osuuskuntalain (421/2013) 16 luvun 1 \&:n 3 momentti.

7 Osakeyhtiölain 13 luvun 2 \& ja osuuskuntalain 16 luvun $2 \S$.

8 Veikko Vahtera - Janne Ruohonen - Anssi Kärki - Lassi Salminen - Laura Saukkola, Selvitys osakeyhtiön velkojiensuojan selventämisestä ja suojamenettelyiden helpottamisesta. Valtioneuvoston kanslia: Valtioneuvoston selvitys- ja tutkimustoiminnan julkaisusarja 2020:37. Saatavissa https://tietokayttoon.fi/julkaisut/raportti?pubid=URN:ISBN:978-952-287-923-3. 
osakeyhtiön varojenjaossa, maksukykyisyystestin sisällön täsmentämiseen, yksityisten osakeyhtiöiden purkamismenettelyyn, velkojiensuojamenettelyihin osakepääoman alentamisen ja yritysjärjestelyiden yhteydessä sekä velkojakäsitteeseen. Näiden teemojen analysoinnin perusteella työryhmä ehdotti useita muutoksia osakeyhtiölakiin. Ehdotukset ovat pitkälti relevantteja myös osuuskuntalain osalta johtuen sen osakeyhtiölakiriippuvuudesta.

Selvitys on viime vuosien keskeisimpiä puheenvuoroja suomalaisen yhteisöoikeuden kehittämisessä. Ehdotukset yksinkertaistaisivat ja liberalisoisivat velkojiensuojasäännöksiä itse velkojiensuojaa heikentämättä. Mikä tärkeintä, ehdotukset pakottavat meitä pohtimaan keskeisiä osakeyhtiölain historialliseen jatkumoon liittyviä kysymyksiä, joista nostan esille kolme ehkä keskeisintä.

Ruotsin vuoden 1944 ja sitä kautta Ruotsin vuoden 1975 ja Suomen vuoden 1978 osakeyhtiölain merkittävimpiä ja soveltajan kannalta hankalimpia säännöksiä olivat oman pääoman menettämisestä seurannut pakkoselvitystila ja yhtiön hallituksen vastuu säännöksen noudattamisesta. ${ }^{9}$ Pakkoselvitystilauhasta ja johdon vastuusta luovuttiin osakeyhtiölailla, johon otettiin osittain EU-lainsäädäntöön perustuvat informointivelvollisuudet, ${ }^{10}$ mutta asian kanssa on senkin jälkeen kipuiltu. Valtioneuvoston kanslian selvityksessä, vaikka ehdotettiinkin ensisijaisesti vain informointisäännösten selkeyttämistä, nostettiin toissijaisesti esille yhteisön johdon, siis ennen kaikkea hallituksen, vastuu velkojia kohtaan yhtiön maksukyvyttömyydestä.

Vastuu maksukyvystä korostuu vieläkin enemmän kaikkea varojenjakoa rajoittavassa maksukykyisyystestissä, jota koskevat ehdotukset ovat selvityksen tärkeimpiä. Ehdotukset koskevat ennen kaikkea hallituksen velvollisuuksia suorittaa maksukykyisyysarviointi, maksukykyisyysarvioinnin ajankohtaa ja arviointia koskevia dokumentointivelvollisuuksia sekä osakepääoman (sekä aiempien ylikurssi-ja vararahastojen) alentamista koskevan velkojiensuojan rakentamista viranomaisvetoisen kuulutusmenettelyn sijaista maksukykyisyystestin varaan. ${ }^{11}$

Sen sijaan tilinpäätökseen perustuvasta tasetestistä ei haluta luopua. Sekä globaalissa, eurooppalaisessa että kansallisessa kontekstissa tasetestejä on arvosteltu viimeiset vuosikymmenet, mutta konkreettiset lainsäädäntötoimet eivät ole saaneet lopulta kannatusta. Runsaan sadan vuoden polkuriippuvuus tasetestistä, keskeisestä 1800-luvun innovaatiosta, on liian vahva. Vähän kuin parisuhteessa, johon on koko ajan tyytymätön, mutta jota ilman ei voi elääkään, tasetesti tulee varmastikin pysymään niin kauan kuin osakeyhtiöiksi tunnistettavia yhteisöjä on olemassa. Osuuskunnissa puolestaan ylijäämän jakaminen jäsenille on ensisijaisesti

9 Ruotsissa yhtiön johdon korvausvastuu perustui lakiin, Suomessa oikeuskäytäntöön, ks. KKO 2012:65 10 Ks. yhtiödirektiivin 58 artikla ja osakeyhtiölain 20 luvun 23 §. Säännös on kopioitu myös osuuskuntalain 23 luvun 23 \&:ksi.

1 Julkisten yhtiöiden osalta osakepääoman alentamiseen liittyvästä velkojiensuojamenettelyst ei voi yhtiödirektiivin 75 ja 76 artiklojen vuoksi luopua, mutta osakeyhtiölain säännöksiä voidaan yksinkertaistaa. ennemminkin poikkeus kuin pääsääntö osuuskunnan tuottaessa hyötyä jäsenilleen heille tuottamiensa palveluiden kautta. ${ }^{12}$

Oikeusministeriö avasi valtioneuvoston kanslian selvityksen lausuntokierrosta varten lokakuussa 2020. Lausuntoaika päättyi 13.12.2020.13 On erittäin mielenkiintoista nähdä, minkälaisen vastaanoton selvityksessä esitetyt ehdotukset saavat, ja kuinka niihin suhtaudutaan oikeusministeriön mahdollisessa jatkovalmistelussa. Kaiken kaikkiaan ne ovat, kuten edellä on jo todettu, keskeisimpiä viime aikoina esitettyjä puheenvuoroja yhteisöoikeudelliseen keskusteluun, pakottaen meidät miettimään keskeisiä osakeyhtiöiden ja osuuskuntien sääntelyyn liittyviä kysymyksiä yhteisön oikeushenkilöllisyyden, yhtiön eri eturyhmien aseman ja yhteisön johdon velvollisuuksien näkökulmasta.
12 Ks. osuuskuntalain 1 luvun 5 §ja 16 luvun $5 \S$

3 Ks. https://oikeusministerio.fi/-/selvitykset-osakeyhtiolain-toimivuudesta-ja-muutostarpeistalausunnoille. 